\title{
閉塞性睡眠時無呼吸症候群の治療
}

$$
\begin{aligned}
& \text { 戸川 清, 宮崎 総一郎 } \\
& \text { 山川 浩 治 }
\end{aligned}
$$

\section{Treatment of Obstructive Sleep Apnea Syndrome}

\author{
Kiyoshi Togawa, M.D., Soichiro Miyazaki, M.D., and Koji Yamakawa, M.D. \\ Department of Otorhinolaryngology, Akita University School of Medicine, Akita
}

\begin{abstract}
Satisfactory results in the treatment of obstructive sleep apnea syndrome (OSAS) depend on precise diagnosis of the site and the severity of obstruction and application of the proper treatment. History-taking including sleep behavior, local and general physical examinations, $\mathrm{X}$-ray examination, fluoroscopy, fiberscopy, polysomnography give us very useful informations for this decision. Among these, polysomnography is the most useful.

OSAS is treated conservatively or operatively as indicated case to case. Among the conservative treatments, body weight reduction with hypocaloric diet is essential in the obese. Nasal CPAP is widely used and known to be effective, however, its long-lasting use is problematic. Medications of antibiotics and antiallergica are useful for reduction of mucosal swelling caused by inflammatory and allergic reactions. Application of a dental prosthesis protruding the mandible is effective. Among the surgical treatments adenotonsillectomy is mainly performed on the infants and children with OSAS. If OSAS is created by intranasal pathologies, intranasal surgeries of various types are applied. When the causative region exists in the palato-pharynx, UPPP is very effective. Tracheostomy gives an instant relief on heavy obstructive dyspnea. If we encounter such heavily disturbed cases, we should not hesitate to do tracheostomy.
\end{abstract}

Key words : obstructive sleep apnea syndrome (OSAS), adenotonsillectomy, uvulopalatopharyngoplasty (UPPP), polysomnography, nasal CPAP

\section{I . はじめに}

睡眠時無呼吸症候群 ${ }^{1)}$ の患者を治療する場合 は，本症の原因，程度の適確な診断が必須の前

秋田大学医学部耳鼻咽喉科学教室

別刷請求： $\mathbf{T} 010$ 秋田県秋田市本道1-1-1

秋田大学医学部耳鼻咽喉科学教室 戸川 清

投稿受付：1989年 6 月23日
提であり，それに応じた治療法が選択されなけ れば期待する効果は得られない。 睡眠中の無呼吸状態は換気流（経口と経鼻） と呼吸運動（胸部と腹部）の有無から閉塞型, 中枢型, 混合型に分類される ${ }^{2)}$ 。三者の比率は閉 塞型が大多数を占めるし, 閉塞型は治療効果が 明らかな例が多い。 


\section{II . 閉塞型睡眠時無呼吸症の原因と診断}

\section{1. 狭窄原因疾患}

睡眠時呼吸障害の原因は多様（表 1）であ る3)。そのうち閉塞性障害の主原因は, 乳幼児は 咽頭扁桃アデノイド増殖症（略してアデノイ ド)，口蓋扁桃高度肥大で，その他鼻疾患による 両側鼻閉例，小顎症，巨舌症，舌根囊胞がみら れる。成人は鼻副鼻腔の閉塞性疾患, 軟口蓋, 特に後口蓋弓や口蓋垂の位置・形態異常, 口蓋 扁桃や舌扁桃の高度肥大，下顎骨形態異常など

\section{表 1 睡眠時呼吸障害の原因}

\section{1. 閉塞性呼吸障害}

1）鼻・副鼻腔疾患

外鼻孔狭窄，鼻中隔彎曲症，アレルギー性鼻 炎, 肥厚性鼻炎, 副鼻腔炎, 鼻茸, 鼻腔悪性 腫瘍

2）上咽頭疾患

後鼻孔閉鎖，Tornwaldt病，アデノイド増殖 症，咽頭扁桃炎，上咽頭腫痬

3）中咽頭疾患

軟口蓋形態異常, 咽頭筋麻痺, 口蓋扁桃肥大 症, 舌甬桃肥大症, 咽後膿痬, 中咽頭腫瘍

4）下咽頭・喉頭疾患

喉頭蓋奇形, 喉頭軟化症, 喉頭蓋浮腫, 喉頭 蓋囊胞, 喉頭蓋腫瘍, 下咽頭腫瘍

5）顎・口腔疾患

小顎症 (単独, Pierre Robin), 巨舌症 (浮腫, 血管腫,リンパ管腫)，下顎骨形態異常，下顎 関節拘縮

6) 頸椎疾患

脊柱彎曲症・硬直症, 変形性脊椎症

7) 神経疾患

両側反回神経麻掉, 球麻渒, Shy-Drager 症候 群(神経系変性)

8）その他の異常

肥満 (単純, 二次的), 末端肥大症, 甲状腺機 能低下症

2. 非閉塞性呼吸障害

1）中枢神経性

脳幹部出血・梗塞・変性・腫瘍, 脳炎, 頸髄 障害 (灰白炎, 変性, 外傷)

2）原発性肺胞低換気症 (Ondine's curse)

3）気管支・肺性 慢性閉塞性肺疾患
がある。肥満の合併はすべての原因について障 害の程度を増強する。これらの原因の 1 つによ つてのみ障害が抢こるとは限らず, 複数原因併 存例も少なくない。個々の原因の程度は比較的 軽くても，複数原因によって障害を増強させる から，障害原因とその程度の診断が正しい治療 の前提となる4)。

\section{2. 狭寉部位と程度の診断}

1) 病状聴取：患者の睡眠状況（目覚めと熟 睡感, 睡眠中途覚醒, 異常行動), 睡眠時の呼吸 状況（周期性か一様性, 呼吸停止の頻動と持続 時間，いびき音の性状，胸・腹部の呼吸性運動 状況), 日中活動状況 (傾眠, 頭重感, 注意散慢, 薬剤常用など）

2）局所・全身所見：上気道各部位の視・触 診, 内視鏡検查, $\mathrm{X}$ 線検查（咽頭部側面，立位 と仰臥位，透視記録），肥満度，顔貌，胸郭形態 から狭窄の部位，程度を推定する。

3 ) 睡眠ポリグラフ検査 polysomnography：自然睡眠状態で脳波 (EEG), 眼球運動 (EOG)，オトガイ筋 EMG，心電図 (ECG)，動 脈血酸素飽和度 $\left(\mathrm{SaO}_{2}\right)$, 経皮 $\mathrm{PO}_{2}$ と $\mathrm{PCO}_{2}$, 呼 気 $\mathrm{O}_{2}$ と $\mathrm{CO}_{2}$ 濃度, 食道内圧, 呼吸曲線 (鼻孔, 口囲, 胸・腹部), 換気量, 呼吸数, 心搏数, い びき音などを連続記録・解析して睡眠障害，睡 眠中の呼吸障害, 循環器への影響の程度を総合 判定する。

われわれは呼吸障害判定基準を食道内圧值に おき, 呼吸性変動幅が $16 \sim 20 \mathrm{~cm} \mathrm{H}_{2} \mathrm{O}$ を軽度, 21 $40 \mathrm{cmH}_{2} \mathrm{O}$ を中等度, $40 \mathrm{cmH}_{2} \mathrm{O}$ 以上を重 度呼吸障害とし，これに $\mathrm{SaO}_{2}$ 低下度 $(80 \%$ 以 下)，その他を加味して治療方針を決めている (表 2 )。

\section{表 2 睡眠時呼吸障害の指標}

1. 食道内圧

2. 動脈酸素飽和度

3. 動脈酸素・二酸化炭素分圧

4. 一回換気量

5. Apnea Index

6. 睡眠段階の変化, 睡眠構築の変化

7. MSLT (Multiple Sleep Latency Test)

8. RR間隔

9.その他(血圧，イビキ音，筋電図など) 


\section{III. 閉塞性睡眠時無呼吸症の治療}

本症の治療は, 閉塞原因の種類, 程度に応じ て保存療法や手術療法の単独または組み合わせ が適宜選択される（表 3 )。

\section{1. 保存療法}

1）薬物療法：上気道粘膜の炎症性腫脹によ る狭窄に対して，抗生物質や非ステロイド抗炎 症剂の全身投与や局所使用(ネブライザー療法, 点鼻使用) が奏効する。特に乳幼児の急性鼻・ 咽頭炎や急性咽頭扁桃炎による呼吸障害例に有 効なことが多い。鼻アレルギーに対しては，抗 アレルギー剂の局所および全身投与をすること で睡眠時呼吸障害が改善されることも経験す る。慢性炎症を伴う軽度障害例に漢方薬投与も 試みられている。利尿剂アセタゾラミド（ダイ アモックス）も用いられるが, 閉塞型無呼吸症 にはあまり有効ではない。抗うつ剤や精神安定 剂は, 閉塞型障害には時に増悪させることもあ り，使用は慎重を要する。

2）体重減少：肥満者に低力ロリ一食, 生活 指導，カウンセリングなどによって減量をはか

\section{表 3 睡眠時呼吸障害の治療}

1. 保存療法

1）上気道疾患 (特に感染) に対する抗炎症療法, 全身投与，局所治療

2）全身性疾患に対する薬物療法

3）減量療法 (食事療法, その他)

4) 経鼻持続陽圧療法 nasal CPAP

5) 生活指導 (節酒, 規則性日課，運動など)

6) 精神心理的カウンセリング

7) 体力調節 (斜位, 側位), 下顎带使用

8）音誘発皮膚刺激装置

\section{2. 手術療法}

1) 鼻腔整復術 (鼻中隔矯正十鼻甲介手術)

2）鼻内副鼻腔手術，鼻茸切除術

3）アデノイド切除術

4）口蓋扁桃摘出術

5）口蓋弓形成術 (uvulopalatopharyngoplasty)

6) 舌扁桃切除術, 舌根正中部分切除術

7）喉頭蓋部分切除術

8）舌骨前方率引固定

9）下顎骨切離・前方移動

10）気管切開術
る。減量に成功すればその効果は大きいが, 体 重の再増加を防ぐには本人や周囲の人々の長期 間の努力が必要である。

3 ）経鼻持続陽圧送気法 nasal CPAP（continuous positive airway pressure) : 中等度以 上の閉塞性障害例には保存療法の中では最も有 効な方法であり ${ }^{5)}$, 欧米諸国では普及している。 われわれも睡眠ポリグラフ検査中に経鼻陽圧付 加をすると食道内圧変動幅は減少し, 呼吸も変 動型から規則性に変わり，血液ガス組成の改善 を観察している(図 1)。しかし本法は，軟口蓋 下垂や咽頭粘膜過剰ひだ形成例には著効を示す が, 舌根沈下, 扁桃高度肥大例ではその効果は さほどでない(表 4 の症例 7，8）。またたとえ 非常に有効であっても, 連夜の鼻マスク装着は わずらわしいようで，中等度の狭窄例では長続 きがしないという。わが国では現在市販の携帯 用装置は 1 種輸入されているが, 近い将来複数 が出るであろう。国産品はまだない。

4) 下顎プロテーゼ（Esmarch）：下顎を 3〜 $5 \mathrm{~mm}$ 前方移動した位置で，上下歯列が咬合 するように作ったプロテーゼを装置することに より，睡眠による下頇沈下を防ぎ，睡眠時呼吸 状態の改善を睡眠ポリグラフで証明した報告が ある6)。本法は nasal CPAPより患者の負担は 軽いようであるが，下顎の前進距離が大きいと 顎関節に負担になる。睡眠時呼吸障害の程度が 強くなければ,下顎帯の外部装着も有効である。

5) 経鼻插管：乳幼児の中・下咽頭狭窄例に 有効であるが，成長による気道断面積増大を保 つには長期にすぎるし，管理も面倒である。

6 ）音響誘発皮膚・筋刺激装置：いびき音に 反応して電気刺激が生じて覚醒反応（筋緊張回 復）をおこして上気道を拡げ，いびきの軽減を はかる器機と, 無呼吸を検出してオトガイ部電 極でオトガイ舌筋を刺激する器械とがある。理 論は面白いが，患者の体動で電極がはずれるこ とがあり, 問題が残っている。

\section{2 . 手術療法}

前述の保存療法で期待した効果が得られず, 睡眠時の呼吸障害が強い場合や，患者が希望し た場合には，原因狭窄部を確認の上でそれに応 じた手術方法が施行される。

1）鼻閉が主因ならば，その病因に応じて鼻 
日気食会報，40（5）, 1989

C.P.A.P. flow

1. Airway P.

2. Exp. $\mathrm{O}_{2}$
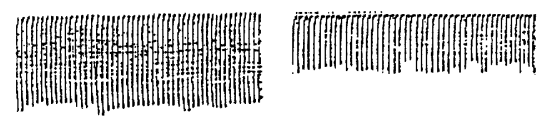

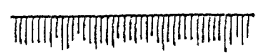

3. Exp. $\mathrm{CO}_{2}$
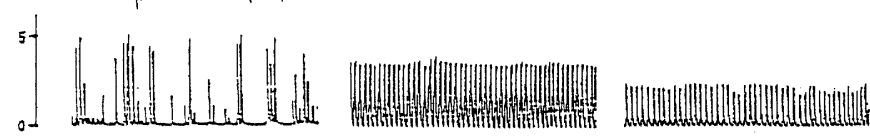

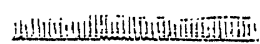

4. tc. $\mathrm{pO}_{2}$

5. tc. $\mathrm{pCO}_{2}$
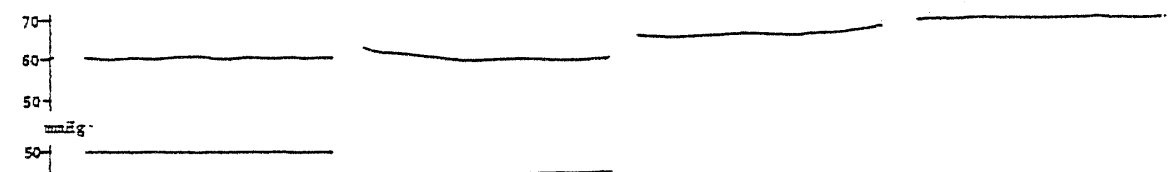

6. $\mathrm{SaO}_{2}$

sot
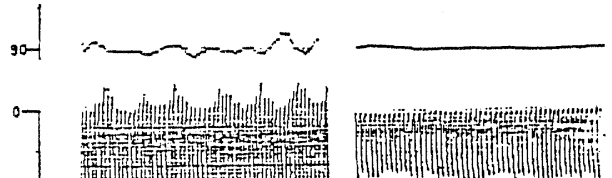

Aiti

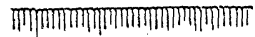

表 4 Effect of CPAP

\begin{tabular}{|c|c|c|c|c|c|c|c|c|c|}
\hline Case & Age/Sex & $\begin{array}{l}\text { Causes of } \\
\text { obstruction }\end{array}$ & $\begin{array}{c}\text { Grade of } \\
\text { OSA. }\end{array}$ & $\begin{array}{l}\text { Minimum } \\
\text { effective CPAP }\end{array}$ & $\begin{array}{l}\text { Change in } \\
\text { P. esoph. }\end{array}$ & $\begin{array}{c}\text { Change in } \\
\mathrm{SaO}_{2}\end{array}$ & $\begin{array}{l}\text { Apne } \\
\text { index }\end{array}$ & & $\begin{array}{l}\text { Effect of } \\
\text { CPAP }\end{array}$ \\
\hline 1 S.E. & $59 \mathrm{M}$ & Palatoptosis & marked & $6 \sim 9 \mathrm{cmH}_{2} \mathrm{O}$ & $\begin{array}{l}50 \\
\sim 80\end{array} \stackrel{10}{\sim 20}$ & $\begin{array}{l}78 \\
\sim 97\end{array} \Rightarrow \stackrel{93}{\sim 97}$ & $55.9 \Rightarrow$ & 0 & definite \\
\hline 2 K.I. & $68 \mathrm{M}$ & $\begin{array}{l}\text { Palatoptosis } \\
\text { Obesity }\end{array}$ & marked & $8 \sim 12$ & $\stackrel{40}{\sim 60} \Rightarrow \stackrel{10}{\sim 15}$ & $\stackrel{56}{\sim 75} \Rightarrow \stackrel{70}{\sim 74}$ & $43.2 \Rightarrow$ & 0 & definite \\
\hline 3 T.N. & $41 \mathrm{M}$ & $\begin{array}{l}\text { Palatoptosis } \\
\text { Obesity }\end{array}$ & marked & $7 \sim 11$ & $\stackrel{40}{\sim 60} \Rightarrow \stackrel{4}{\sim} 8$ & $\stackrel{46}{\sim 65} \Rightarrow \stackrel{75}{\sim 80}$ & $10.6 \Rightarrow$ & 0 & definite \\
\hline 4 U.A. & $56 \mathrm{M}$ & $\begin{array}{l}\text { Palatoptosis } \\
\text { Obesity }\end{array}$ & moderate & $4 \sim 8$ & $\stackrel{20}{\sim 40} \Rightarrow \stackrel{4}{\sim} 8$ & $\stackrel{75}{\sim 96} \Rightarrow \stackrel{90}{\sim 98}$ & $8.7 \Rightarrow$ & 0 & definite \\
\hline 5 S.M. & $37 \mathrm{M}$ & $\begin{array}{l}\text { Palatoptosis } \\
\text { Obesity }\end{array}$ & marked & $6 \sim 9$ & $\stackrel{40}{\sim 60} \Rightarrow \stackrel{4}{\sim} 8$ & $\stackrel{82}{\sim 96} \Rightarrow \stackrel{94}{\sim 98}$ & $1.0 \Rightarrow$ & 0 & definite \\
\hline 6 F.S. & $51 \mathrm{~F}$ & $\begin{array}{l}\text { Palatoptosis } \\
\text { Obesity }\end{array}$ & marked & $3 \sim 6$ & $\stackrel{20}{\sim 30} \Rightarrow \stackrel{4}{\sim}$ & $\stackrel{42}{\sim 98} \Rightarrow \stackrel{86}{\sim 98}$ & $0 \Rightarrow$ & 0 & definite \\
\hline 7 S.F. & $54 \mathrm{M}$ & $\begin{array}{l}\text { Stenosis at } \\
\text { root of tongue }\end{array}$ & marked & $15 \sim$ & $\stackrel{20}{\sim 40}_{\Rightarrow x} \rightarrow x$ & $\stackrel{60}{\sim 80} \Rightarrow \stackrel{48}{\sim 60}$ & $27.8 \Rightarrow$ & $x$ & slight \\
\hline 8 K.U. & $24 \mathrm{M}$ & $\begin{array}{l}\text { Tonsillar } \\
\text { hypertrophy }\end{array}$ & marked & $15 \sim$ & $\stackrel{60}{\sim 80} \Rightarrow \stackrel{60}{\sim 80}$ & $\stackrel{26}{\sim 97} \Rightarrow \stackrel{20}{\sim 80}$ & $52.1 \Rightarrow$ & 52.7 & no change \\
\hline
\end{tabular}


腔整復術 (鼻中隔矯正術十鼻甲介手術), 鼻内副 鼻腔手術を選択施行する。

2 ）幼小児鼻閉の主原因の一つであるアデ， イド増殖症には，アデノイド切除を行う7)。原因 が口蓋扁桃高度肥大ならば扁桃摘出術を行う。 われわれが施行したほぼ全例に自他覚所見の著 しい改善が得られた ${ }^{8)}$ 。

図 2 はアデノイド増殖症による高度の睡眠時 無呼吸を呈した 7 歳男児の術前と術後の睡眠経 過の比較図である。術前には入眠時の睡眠深化 が妨げられて浅眠状態で経過し，睡眠時間が延 長している。無呼吸は頻繁に発生し，食道内圧 変動幅は30 $40 \mathrm{cmH}_{2} \mathrm{O}$ に達している。術後は 正常の睡眠パターンに復し，初期に深睡眠期に 到達し, 中途覚醒はみられない。無呼吸は激減 し, 主に REM 期に数回みられた。食道内圧変動 も $10 \mathrm{cmH}_{2} \mathrm{O}$ 前後と正常範囲内で，かつ一定と
なった。

3 ）軟口蓋，特に後口蓋弓下垂や過長口蓋垂 が主因であれば，咽頭形成術 uvulopalatopharyngoplasty (UPPP) を行う。本法の原型は1960 年代に池松9)，1970年代 Quesada などにより行 われていたが, Fujita ら(1981) ${ }^{10)}$ の詳細な術式 発表を契機に世界的に広まった。これは polysomnographyによる睡眠研究の著しい発 展と機を一にしている。現在は種々の変法が発 表されている。

われわれは，扁桃摘出後に口蓋垂の両側に垂 直切開を前口蓋弓頂の $1 \mathrm{~cm}$ 上まで加え，その 頂点から下・側方へ弧状に粘膜を切離し, 前面 は前口蓋弓の曲面に合わせる。後面は後口蓋弓 を下・後方へ切離を進め, 扁桃床創面に達した ら後口蓋弓を前方に牽引し，楽に扁桃床をおお い前口蓋弓と合う線で下方へ切り進む。扁桃床

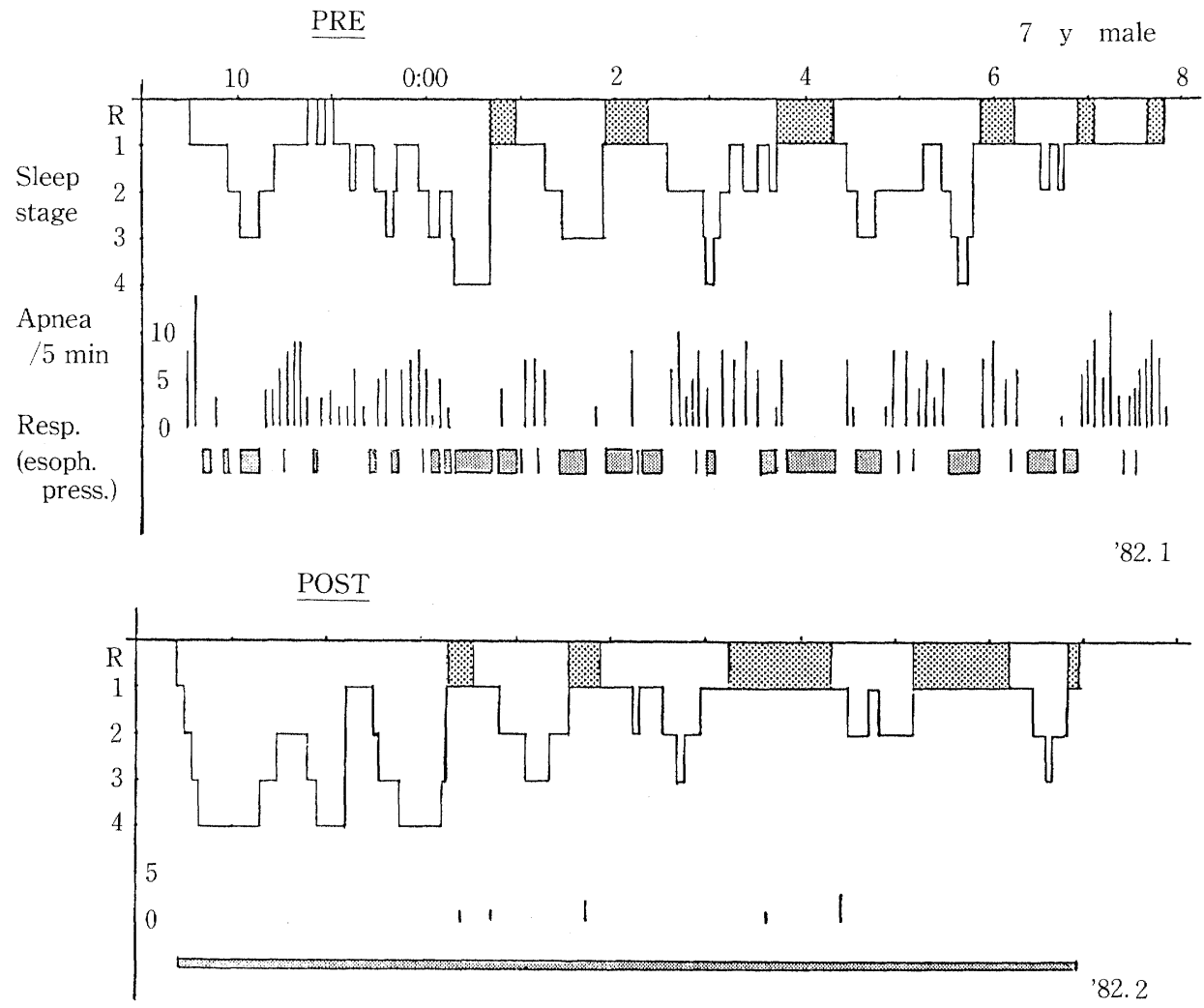

図 2 アデノイド増殖による高度鼻呼吸障害例の術前術後の睡眠経過図 
下端の高さで後口蓋弓に水平の割を入れて, 後 口蓋弓を前口蓋弓と筋ごと縫合する。最後に口 蓋垂を上極から $1 \sim 1.5 \mathrm{~cm}$ 残して切断・縫合す る (図 3$)^{11)}$ 。手術効果は少数の例外を除いて満 足のゆくものであった。術前後の検査一式が揃 った例の比較で分かる。効果不十分な原因は, 肥満者や軟口蓋以外に下顎後位や舌根〜下咽頭 の異常合併などによった。術後合併症は短期間 液体の鼻への逆流が $10 \%$ あったほか, 咽頭刺激 感・異物感, 味覚異常がみられた。

4 ）舌根部に原因があれば, 舌扁桃切除術や 舌根部分切除術(藤田) ${ }^{12)}$ を行う。著者はまだ経 験していないが, 本法の適応となる例がわれわ れの UPPP 施行例の中にいるから, 今後追試の

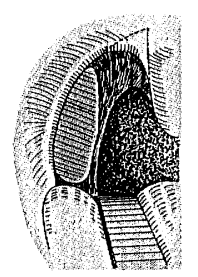

(1)

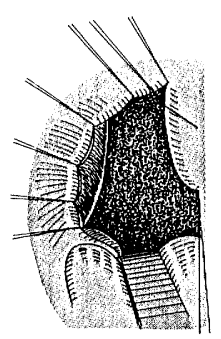

(4)

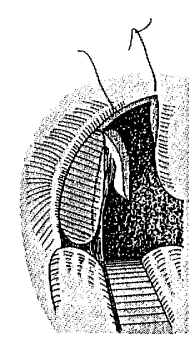

(2)

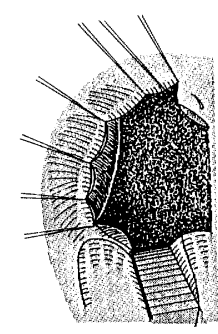

(5)

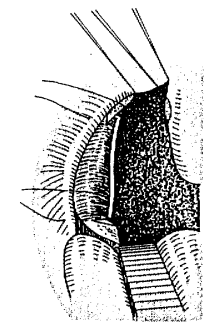

(3)

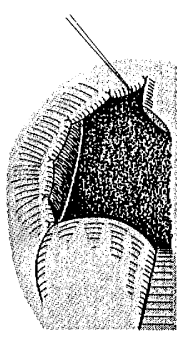

(6)
図 3 咽頭（口蓋垂・口蓋・咽頭）形成術（UPPP） (1)形通り扁摘を行う。uvula 側縁から上方へ正中線 と平行に粘膜切開をおき, (2)前口蓋弓頂点より $1 \mathrm{~cm}$ 位上まで達したら側・下方へ弧状に切開を進める。 (3)扁桃床創面に達したら，そのまま下へ切り進み, 扁桃床下端の高さで後口蓋弓を横切し，それで扁桃 床創面を覆い, 自由縁を前口蓋弓と縫合する。三角 窩付近横切の際，血管に注意する。

(4)口蓋弓の縫合が終わったら，口蓋垂尖端に系をか けておき,均衡を保ちつつ切開予定線を色づけする。 (5)口蓋弓上縁から $1 \mathrm{~cm}$ 位, 離れた部分で切断する。 (6できた創面を対称的に縫合する。
予定である。

5 ）喉頭縁に原因があれば，喉頭蓋部分切除 術や披裂喉頭蓋ひだの部分の切除 (レーザー法) が行われる。

6）下顎後位や小顎症に対しては，下澦骨切 断・前方移動術が報告されているが13), 侵襲が大 きいわりには長期成績は良いとはいえないよう だ。

7 ) 気管切開術は閉塞性睡眠時無呼吸症, 特 にその原因が下咽頭，喉頭にある場合の最も有 効な手段である。欧米では経鼻 CPAP や低力口 リー食事療法などが無効な例に適応されてい る。こうした症例は高度肥満が多いので，気管 口永続確保，特に前頸皮膚のたるみで気管口が 開塞されないように種々の工夫がなされてい る14)。われわれは Pickwick 症候群の 3 例に気 管切開術を UPPP と併施し, 高度の心陰影拡大 が数か月以内に著しく縮小したものを経験して いる(図 4)。

気管切開術は肥満者や短頸者に対する UPPP 施行の際にも行い, 術後 (抜管後) の呼 吸障害を予防する。

原因が複数ある症例には二，三の術式が併施 されることがある。すなわち適応を誤れば，手 術をしても良い効果が得られないのは当然であ る。またどの手術を行っても術後の正しい管理 と経過観察が大切である。

\section{IV. おわりに}

睡眠時無呼吸症候群のうち, 閉塞性呼吸障害 に対する治療法の種類を保存療法と手術療法に 大別し, 個々の方法やその適応, 治療効果, 問 題点などを述べた。またこれらの治療効果の客 観的判定法として polysomnography が有用で あることを例示した。

本症は睡眠自体に対してはもとより, 呼吸機 能, 循環機能, 精神機能に悪影響を及ぼし, 高 度の障害が持続すると胸郭変形, 高血圧, 心不 全や突然死の原因ともなるので, 本症の疑いが あれば積極的に局所および全身的検索を進め, その原因部位, 気道狭窄の程度を正確に診断し, それに応じた適切な治療を行う必要がある。 


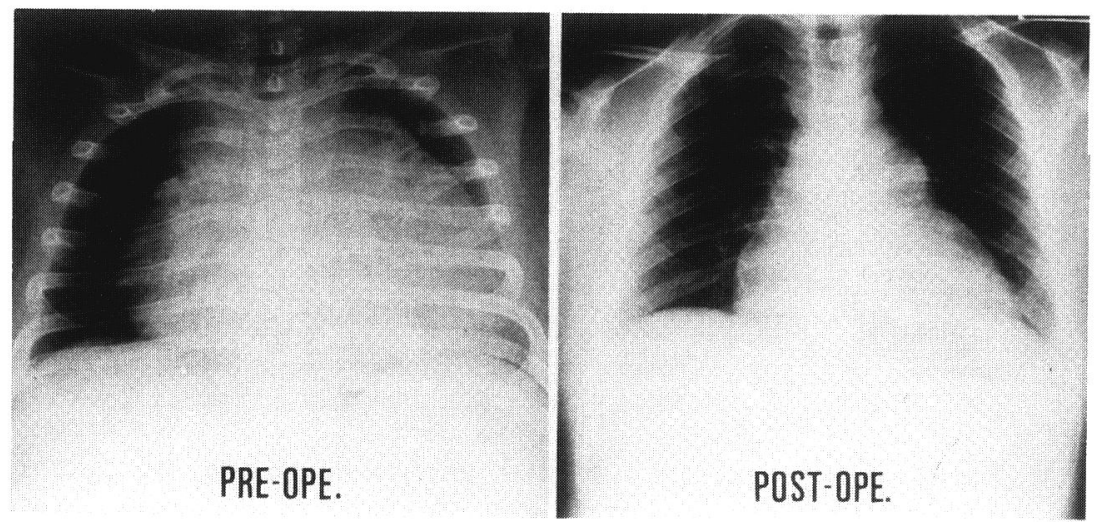

図 4 Pickwick 症候群 (14歳, 男)に対する治療 (気 管切開＋咽頭形成術）の効果

〔左図〕身長 $164 \mathrm{~cm}$, 体重 $106 \mathrm{~kg}$, 肺性心。

〔右図〕術後 70 日, 体重 $80 \mathrm{~kg}$, 心所見改善。

\section{文献}

1) Guilleminault, C., et al.: The sleep apnea syndromes. Annu. Rev. Med., 27:465-484, 1976.

2 ) Gastaut, H., et al. : Polygraphic study of the episodic diurinal and nocturnal (hypnic and respiratory) manifestations of the Pickwick syndrome. Brain Res., 2: 167-186, 1966.

3） a ) 戸川 清：いびき.耳喉, 46:685-690, 1974. b ）同：睡眠障害の原因としての耳鼻咽喉科領 域疾患. 呼と循, 37：17-20, 1989.

4) Togawa, K., Miyazaki, S., Yamakawa, K., et al.: Obstructive sleep dyspnea-diagnosis and treatment-. Acta Otolaryngol., Suppl., 458: 167-173, 1988.

5 ) Sullivan, C.E., et al. : Reversal of obstructive sleep apnea by continuous positive airway pressure applied through the nares. Lancet, $1: 862-865,1981$.

6 ) Kloß, W., Meier-Ewert, K., and Schäfer, H. : Zur Therapie des obstruktiven Schlaf-ApnoeSyndroms. Fortschr. Neurol. Psychiat., 54 : 267-271, 1986.

7 ）今野昭義, 戸川 清：乳幼児における咽頭扁桃,
口蓋扁桃肥大と睡眠中の上気道狭窄について。 耳喉, 49:7-15, 1977.

8 ）宮崎総一郎・他：小児のアデノイド・ロ蓋扁桃 肥大による睡眠時呼吸障害と手術治療。臨床脳 波, 29:732-738, 1987.

9 ）池松武之亮：いびきの研究第 4 報。いびきの一 治療法。日耳鼻, $64 ： 434,1961$.

10) Fujita, S., et al.: Surgical correction of anatomic abnormalities in obstructive sleep apnea syndrome: uvulopalatopharyngoplasty. Otolaryngol. Head Neck Surg., 89 : 923934, 1981.

11）戸川 清：いびきの治療. 図説耳鼻咽喉科講座一 3. 鼻副鼻腔疾患 (本多芳男他編集), pp.246-247, メジカルビュー社, 東京, 1984.

12) Fujita, S., et al. : Midline later glossectomy as treatment for obstructive sleep apnea syndrome. (submitted)

13) Wittig, R., et al.: Mandibular advancement as a treatment of sleep apnea syndrome. Sleep Res., $12: 296,1983$.

14) Fujita, S., et al.: Permanent tracheostomy with advancement of skin flaps, indication, technique and results. Poster presentation, Annual Meeting AAO \& HNS, 1982. 